\title{
Importance of professional ethics and corporate social responsibility within business studies curriculum within context global economy
}

\author{
Tatjana Daudisa ${ }^{1}$, Velga Vevere $^{2, *}$ \\ ${ }^{1}$ EKA University of Applied Sciences, Latvia \\ ${ }^{2}$ EKA University of Applied Sciences, Latvia
}

\begin{abstract}
Businesses today have to juggle between the need to survive due to increased competition and the pressure to become socially and environmentally responsible business entity. Consistent with the intensification of discussion about the importance of embracing CSR among businesses, the issues now has expanded to the concern over the future of CSR. In view of this, the future of CSR will depend on how the future generations perceive the importance of embracing CSR in business operations. The purpose of the current study is to research the business students' perception of importance of ethics and corporate social responsibility courses within their curriculum. The quantitative research design is applied in the study - the target group survey using 7-point Likert scale questionnaire, nonprobability purposive sampling $(n=131)$. The research question posed in the current article is the following: Does business students' attitude towards CSR and ethics depend upon taking these courses as part of BBA and MBA curriculum? The result of the study - the mapping of students perceptions and attitudes towards ethical aspects taught at the university. The practical implications of the current study are of improvement of BBA and MBA curriculum to meet the needs of the 21 st century in the globalized business environment.
\end{abstract}

\section{Introduction}

Globalization of society, new levels of complexity and contradiction create tensions for which education is expected to prepare individuals and communities by giving them the capability to adapt and to respond. At the same time, there is increase of cultural and religious diversity, that could lead either to cooperation and solidarity or an increase in cultural and religious intolerance, identity-based political mobilization and conflict. Businesses today have to juggle between the need to survive due to increased competition and the pressure to become socially and environmentally responsible business entity. Consistent with the intensification of discussion about the importance of embracing Corporate social responsibility among businesses, the issues now has expanded to the

\footnotetext{
* Corresponding author: velga.vevere@gmail.com
} 
concern over the future of CSR. Importance of CSR is still rising. This is evidenced by the fact that the aim of modern company is not only to be innovative but responsible for its actions and excellent in every activity.

Corporate social responsibility is essentially a concept whereby companies decide voluntarily to contribute to a better society and a cleaner environment. Currently, there is still no consensus on a broad definition for CSR. On various occasions the notion of CSR has been used as a synonym for business ethics. It has also been associated to corporate philanthropy and was related to environmental policy. CSR has been renamed corporate social performance and corporate citizenship. The European Commission's "Green Paper: Promoting a European Framework for Corporate Social Responsibility" as of 2001 describes CSR "as a concept whereby companies integrate social and environmental concerns in their business operations and their interaction with their stakeholders on voluntary basis." [1] The definition stresses the main points, that CSR involves social and environmental issues of business strategies, and it is based on the principle of voluntarism. Besides that, the definition points out the importance of engagement of internal and external stakeholders, the internal stakeholders being primarily employees and shareholders (this involves such issues as investing in human capital, health and safety, and managing change), while the external stakeholders are business partners and suppliers, customers, public authorities and NGOs representing local communities, as well as the environment.

Education must find ways of responding to such challenges, taking into account multiple worldviews and alternative knowledge systems, as well as new frontiers in science and technology such as the advances in neurosciences and the developments in digital technology. Rethinking the purpose of education and the organization of learning has never been more urgent. [2] Education alone cannot hope to solve all development challenges, but a humanistic and holistic approach to education can and should contribute to achieving a new development model. The integral part of this new model, no doubt, is courses on corporate social responsibility and business ethics (integral or not integral) offered to business students as future generation of entrepreneurs. Education represents a key component of adaptive capacity, as the knowledge, skills and behaviours necessary to adapt lives and livelihoods to the ecological, social and economic realities of a changing environment must be transmitted to the present and next generations. The distinctive feature of the contemporary world is globalization of business environment and diversification of the labour force, as well as internationalization of education (student and academic staff mobility, joint teaching programs, etc.).

Approaches to teaching business ethics and CSR can be divided in two broad groups the integrative and non-integrative ones. The first group of researchers [3] [4] [5] represents the opinion that ethical issues should be essentially integrated within various subjects in a targeted manner (in accordance to industry needs, for example), it presupposes also adding the philosophical reasoning to every-day case studies and analyses. Although there are many good reason s to require a standalone business ethics course in the BBA and MBA curricula, this is not always the case, since business ethics professors are often criticized for being isolated from the industry issues. Whereas the latter approaches stress the importance of the stand-alone business ethics course, perhaps differentiated according to needs of BBA and MBA students - thus, there is a proposal to offer bachelor students the experience based education, with aim to create self-awareness, while master students are to take a special course drawing on their previous learning and work experience. [6] [7] The innovative teaching methods, including lectures, interactive studies, guest lectures are required to fulfil the aims of the subject. [8] Still, for the purpose of the present investigation, among publications on the ethics education, we would like to single out the one entitled "Teaching Business Ethics Through Strategically Inserted Micro-insertions." [9] The authors of the publication stress the importance of the micro-insertions that are 
defined as "small scale insertions of ethics instructions" throughout a course, producing a larger number of ethics mini-lessons during a semester, each taking only a few minutes. [10] In other words, particular themes are developed and delivered by the ethics professor or by the guest lecturer amidst the rest of the themes as a workshop, a seminar, a lecture, a class activity, etc. The micro-insertion offers a way to communicate ethics using a "lowdose" approach. In our opinion, the micro module of negotiation ethics is a promising way of engaging students in discussions of ethical issues.

Matten and Moon [11] present the results of a survey on CSR education (teaching and research) in Europe. The basis for their survey was to try to identify whether business schools were making a concerted effort to incorporate social responsibility courses into the curriculum. The authors found that, in general, business schools are trying to find new ways to include business ethics and CSR courses in the curriculum, but that this was a new and yet unproven process. The survey also showed that the most influential persons driving the CSR agenda are specific faculty members. Interesting results were presented by Moon and Orlitzky [12] in their comparison of American and European business education models, paying a special attention to social responsibility issues. According to them, American business schools have closer connection to corporations and their CSR practices as grounds of their sustainability. R. Reis and others [13] analyse students' perceptions on issues related to Corporate Social Responsibility (CSR) in higher education in Portugal in order to understand how students perceive its conceptualization and operationalization. What is even more important - this research draws conclusions upon the effectiveness of embedded CSR teaching, that is, integration of CSR principles in the wider curriculum. This is necessary to facilitate the holistic transformation towards more responsible and sustainable business knowledge. Although business students may need training in ethics and moral reasoning more than most other students, not always such subjects are included in the business. [14] Other researchers have [15] [16] analysed four predictors of CSR attitudes: students' materialistic values, two ethical ideologies or stances, and spirituality. N. Cornelius and others [17], in their study, pay attention to business schools' responsibility to provide practitioners with training in the basics of ethics, which would ideally act as a catalyst to stimulate socially and ethically managed business organizations. The importance of practical (including ethical) training in business schools is stressed [18], the authors believe that many business schools have developed in the wrong direction by treating business as solely academic discipline. Questions (problems and opportunities) regarding inclusion of CSR and ethics within business school curricula either as independent or insertion models have been tackled by Wong, Long, and Elankumaran [19] and the author of the present article. [20]

The research question of the current investigation is the following: Does business students' attitude towards CSR and ethics depend upon taking these courses as part of BBA and MBA curriculum?

\section{Methods}

The purpose of this research is to examine the attitudes of business students towards corporate social responsibility, investigate the differences in those attitudes and to establish how education process can influence students' understanding of corporate social responsibility. The survey was conducted among undergraduate and graduate students of all years in two private business universities (business schools) in Riga. Approaching the students involved in the MBA and BA studies provided a first-hand account of what socialethical issues they believe to be of importance. Students were approached with the request to be questioned about their opinion during the class, they were given certain time to fill out the questionnaire without any interruption and control of the professor. The respondents 
received all necessary information about the purpose and procedure of the research, as well as their anonymity was guaranteed. The questionnaire was developed based on the literature study; it consisted of 34 questions divided into three blocks according to subject of research, plus general questions regarding age, gender, work experience, study level, nationality, etc. The questionnaire design was a 7-point Likert scale answers varying from "not at all appropriate" (value - 1) to "very appropriate" (value -7 ). The answers received were divided into 2 groups according to respondents' answer to the question (yes or no) if they have received formal training in CSR and business ethics. The survey included statements (the statements and their mean value, as well as mean and mode values are depicted in the findings part of the present article). The first block of statements (altogether 10) was devoted to students' attitude to good business practices and sustainability, in general. Let us mention a few statements, among others: "Good ethics is good business", "Responsible social behaviour leads to a long term profitability of a company", "Within a business firm, the purpose justifies the means", etc. The second statement block could be deemed as perceived importance of corporate social responsibility practices. Altogether this block consisted of 15 statements, such as: "Health and safety issues", "Equal opportunities for employees", "Contribution to regional socio-economic development", "Involvement in community interests", etc. The third block of statements regarded business education (3 statements): "All business students must attend a course in business ethics and corporate social responsibility", "My business education is preparing me to manage business and societal issues", and "My business school has ethical and sustainability aspects integrated in general curriculum".

Population sampling. Once the research design was established, it was necessary to make a decision about the sampling unit (a unit of population chosen during the sampling process; the unit should contain one or more elements describing the population). Participants of the survey were chosen according to the principle to include BBA and MBA students of two private business schools in the study year of 2018/2019. This procedure can be described as a non-probability purposive sampling, i.e. single stage procedure where sampling unit contains only one element, namely, involvement in the business studies (regardless the level). [21] Altogether $131 \mathrm{BA}$ and MBA students were surveyed. 8 questionnaires were recognized as invalid, so the results of 123 answers were analysed. The descriptive statistics were applied to calculate the arithmetic mean, mode and median. After that the comparative analysis of the results was performed.

There were two main limiting factors of the current research: (1) only two private universities were involved in the current investigation (there could or could not be some differences if students of public universities were be surveyed); (2) the results were analysed according to only one main indicator (i.e., attendance of CSR and business ethics courses). Despite these limitations, we believe that our research was representative, it demonstrated at least some prevailing tendencies. The obtained data could be employed to work out proposals for business studies curriculum improvement.

\section{Results and discussion}

The main discriminating indicator of the current research was business students' involvement in CSR and business ethics courses. Altogether there were 123 valid questionnaires, the answers were divided into two almost identical groups: 59 students had formal training, 64 did not have formal training in CSR and ethics. The first block of the questions was related to business students attitude towards socially responsible and ethically viable business practices, in general. The statements were either positive (see Table 1) or negative oriented (see Table 2), so in the positive statements the highest the mean value is, the better, while in the negative statements - the lower mean value, the 
better attitude (for example, the mean value of the statement 4.14 as opposed to 4.51 demonstrates the higher level of ethical awareness). All answers were divided into two groups - A (students who have taken CSR and business ethics courses) and B (students who have not attended CSR and business ethics courses.

Table 1. Arithmetic means of the general attitudes towards socially responsible business practices, positive statements (A-students who have taken CSA and business ethics courses; B - students who have not taken these courses)

\begin{tabular}{|l|c|c|}
\hline \multicolumn{1}{|c|}{ Statement } & \multicolumn{2}{|c|}{$\begin{array}{c}\text { Arithmetic } \\
\text { Mean }\end{array}$} \\
\hline & A & B \\
\hline Good ethics is good business & 5.91 & 5.56 \\
\hline $\begin{array}{l}\text { Responsible social behavior leads to a long term profitability } \\
\text { of a company }\end{array}$ & 5.45 & 4.8 \\
\hline $\begin{array}{l}\text { I believe that corporations need to act according to societal } \\
\text { and ethical norms }\end{array}$ & 5.42 & 5.69 \\
\hline $\begin{array}{l}\text { I feel that as a future employee of a company I can have a } \\
\text { positive impact on the development of society }\end{array}$ & 5.41 & 5.22 \\
\hline $\begin{array}{l}\text { The profit performance of a firm is directly related to its } \\
\text { social responsibility }\end{array}$ & 4.47 & 4.59 \\
\hline \multicolumn{1}{|c|}{} & 5.33 & 5.17 \\
\hline
\end{tabular}

Although the results do not exhibit sizable differences between mean values assigned by both groups (those who have or have not attended the specialized courses), it is possible to detect some tendencies in student attitudes. The summary mean value of the positive statements is higher for students who have learned the basics of CSR (group A: $\mathrm{X}^{--}=5.33$ ) than for students who have not attended the fore mentioned courses (group B: $\mathrm{X}^{-}=5.17$ ). Thus, we can conclude that, in general, theoretical and practical knowledge gained during studies have played a certain role in raising students' ethical awareness. On the other hand, some statements yielded rather unexpected results, namely, the group B exhibited more positive attitude to issues related to company business performance and corporate governance $\left(\mathrm{X}^{-}=4.8 ; \mathrm{X}^{-}=5.69 ; \mathrm{X}^{-}=4.59\right)$. This fact can be at least partly explained by the fact that this particular research didn't take into account respondents' previous work experience and study level. At the same time, the results depicted in the Table 2 (assigned values to the negative statements) are more consistent - in almost all statements respondents from group A demonstrated slightly higher level of ethical awareness and responsibility. 
Table 2. Arithmetic means of the general attitudes towards socially responsible business practices, negative statements (A-students who have taken CSA and business ethics courses; B - students who have not taken these courses)

\begin{tabular}{|l|c|c|}
\hline \multicolumn{1}{|c|}{ Statement } & \multicolumn{2}{|c|}{$\begin{array}{c}\text { Arithmetic } \\
\text { Mean }\end{array}$} \\
\hline & A & B \\
\hline $\begin{array}{l}\text { I believe it is a difference between what businesses } \\
\text { communicate and what they actually do }\end{array}$ & 4.95 & 5.27 \\
\hline $\begin{array}{l}\text { In order to be a good corporate citizen, it is often needed to } \\
\text { compromise one's ethics }\end{array}$ & 4.3 & 3.61 \\
\hline Within a business firm, the purpose justifies the means & 4.3 & 4.32 \\
\hline $\begin{array}{l}\text { I am concerned that in my future job, my personal values } \\
\text { will conflict with those of business world }\end{array}$ & 4.14 & 4.51 \\
\hline $\begin{array}{l}\text { The ethical standards of large businesses are worse than the } \\
\text { standards of small business }\end{array}$ & 2.22 & 3.54 \\
\hline & 3.98 & 4.25 \\
\hline
\end{tabular}

The summary mean values are $\mathrm{X}^{-}=3.98 ; \mathrm{X}^{-}=4.24$ for the groups $\mathrm{A}$ and $\mathrm{B}$ accordingly. Only one statement ( "In order to be a good corporate citizen, it is often needed to compromise one' s ethics” ) is inconsistent with the rest of the values assigned, that is, the group A exhibits the willingness to compromise personal value systems in the name of the greater good $\left(\mathrm{X}^{-}=4.3 ; \mathrm{X}^{-}=3.61\right.$ for the groups $\mathrm{A}$ and $\mathrm{B}$ accordingly). This particular result is in the need of further, especially in the light of ethics education. In addition, we can see that students are rather skeptical to the contents of corporate communications. The second block of the statements regarded the perceived importance of the CSR and business ethics issues (see Table 3).

The ranking of responsibility and ethical issues is mostly similar for both groups, except a two particular issues, one related to the responsible relationships with stakeholders (group B does not assign this matter a great importance, it takes only the 11th place in the ranking), whereas group A does not see the issue of professional development and lifelong learning as particularly significant. We believe that incongruities within both statements can be explained by the fact that the respondents are only in the beginning of their professional career regardless the study level. Still, the results pinpoint the fact that among both group respondents the central social and ethical issues are related to health, environment and product information (the ranking is almost identical).

The third block of statements was related to the importance of the CSR and business ethics studies (see Table 4). 
Table 3. Perceived importance of CSR and business ethics issues (A-students who have taken CSA and business ethics courses; B - students who have not taken the courses)

\begin{tabular}{|l|l|l|}
\hline \multicolumn{1}{|c|}{ Statement } & \multicolumn{2}{|c|}{ Ranking } \\
\hline & \multicolumn{1}{|c|}{ B } \\
\hline Health and safety issues & 2 & 1 \\
\hline Useful and truthful information about the products & 3 & 2 \\
\hline Respect for environment & 3 & 7 \\
\hline Balance between work, family and leisure & 4 & 4 \\
\hline Quality products adapted to consumers' expectations & 5 & 11 \\
\hline Responsible relationships with stakeholders & $6 / 7$ & 8 \\
\hline Ethical commitment to suppliers and distributors & $6 / 7$ & 6 \\
\hline Equal opportunities for employees & 8 & 6 \\
\hline Professional development and lifelong learning & 9 & 5 \\
\hline Better information throughout the company & 10 & 9 \\
\hline Contribution to regional socio-economic development & 11 & 10 \\
\hline Fair play in the relationships with competitors & 12 & 13 \\
\hline Collaboration with Public Administration and NGOs & 13 & 14 \\
\hline Involvement in community interests & 14 & 12 \\
\hline Volunteering activities for employees & 15 & 15 \\
\hline
\end{tabular}

Table 4. Attitudes towards CSR and ethics education (A-students who have taken CSA and business ethics courses; B - students who have not taken the courses)

\begin{tabular}{|l|c|c|}
\hline \multicolumn{1}{|c|}{ Statement } & \multicolumn{2}{|c|}{$\begin{array}{c}\text { Arithmetic } \\
\text { Mean }\end{array}$} \\
\hline & A & B \\
\hline $\begin{array}{l}\text { All business students must attend a course in business ethics } \\
\text { and corporate social responsibility }\end{array}$ & 5.72 & 5.75 \\
\hline $\begin{array}{l}\text { My business education is preparing me to manage business } \\
\text { and societal issues }\end{array}$ & 5.41 & 4.98 \\
\hline $\begin{array}{l}\text { My business school has ethical and sustainability aspects } \\
\text { integrated in general curricula }\end{array}$ & 5.34 & 4.25 \\
\hline & 5.49 & 4.99 \\
\hline
\end{tabular}

The results demonstrate that overall students perceive the importance of CSR and business ethics courses, those who have had some previous experience hold higher regard $\left(X^{-}=5.49\right)$ than respondents from the group $B\left(X^{-}=4.99\right)$. Still, there is a place for 
improvement in the business school curricula, especially in the field of teaching format (choice between the free standing courses or insert modules, or deeper incorporation within other subjects).

\section{Conclusion}

The research question of the current research was the following: Does business students' attitude towards CSR and business ethics depend upon taking these courses as part of BBA and MBA curriculum?

To answer this question, the survey of 131 business students of 2 private universities in Latvia was performed (123 questionnaires were recognized as valid). The questionnaire consisted of three blocks of statements (for evaluation we used 7-point Likert scale): the first block concerned students' general attitude towards CSR and business ethics; the second block - perceived importance of the CSR and ethics issues; the third block concerned ethics education.

The yielded results are inconclusive - the viable differences between answers of those who had attended and had not attended courses in business ethics and/or CSR appear only in the 3 rd block of questions (in some cases results were opposite to the ones expected). This can be explained by the fact that in the current research such factors as previous work experience and study level were not taken into account. Despite this the results demonstrate students' readiness to be taught such subjects. At the same time, the investigation raised questions about teaching formats (free standing courses, insert modules or thorough integration). In our opinion, all three approaches are possible depending on the schools' curricula formation principles. In case, if there is no space for free standing courses we propose to work out insert modules (10-12 academic hours), that can be compatible with such courses as management, marketing, corporate communications, etc.

\section{References}

1. COM, Green Paper. Promoting European Framework for Corporate Social Responsibility (European Commission, Brussels, 2011)

2. UNESCO, Rethinking Education. Towards a global common good (UNESCO Publishing, Paris, 2015)

3. A. Rasche, D. U. Gilbert, I. Schedel, Cross-Disciplinary Ethics Education in MBA Programs: Rhetoric or Reality? Academy of Management Learning \& Education, 12, 1 , 71-78 (2013)

4. A. Acevedo, But, Is It Ethics? Common Misconceptions in Business Ethics Education. Journal of Education for Business, 88, 63-69 (2013)

5. G. Tello, D. Swanson, L. Floyd, C. Caldwell, Transformative Learning: A New Model for Business Ethics Education. Journal of Multidisciplinary Research, 5, 1, 105-120 (2013)

6. E. L. Felton, R. R. Sims, Teaching Business Ethics: Targeted Outputs. Journal of Business Ethics, 60, 377-391 (2005)

7. R. R. Sims, E. L. Felton, Designing and Delivering Business Ethics Teaching and Learning. Journal of Business Ethics, 63, 297-312 (2006)

8. P. N. Rajeev, Teaching Business Ethics: An Integrated Approach. Journal of International Business Ethics, 5, 2, 45-51 (2012) 
9. A. Slocum, S. Rohlfer, C. Gonzalez-Canton, Teaching Business Ethics Through Strategically Integrated Micro-Insertions. Journal of Business Ethics, 125, 45-58 (2014)

10. K. Riley, M. Davis, A. C. Jackson, J. Maciukenas, Ethics in the Details: Communicating Engineering Ethics via Micro-Insertion. Tutorial. IEEE Transactions on Professional Communication, 52, 1, 95-108 (2009)

11. D. Matten, J. Moon, Corporate Social Responsibility education in Europe. Journal of Business Ethics, 54, 4, 323-337 (2004)

12. J. Moon, M. Orlitzky, Corporate social responsibility and sustainability education: A trans-Atlantic comparison. Journal of Management \& Organization, 17, 5, 583-603 (2011)

13. R. Reis, M. von Schwedler, S. Gomes, Corporate Social Responsibility Knowledge in Higher Education Students in Portugal. Proceedings of The 16th European Conference on Knowledge Management (Univ. of Udine: Undine, 2015, 628-634)

14. L. Gardiner, P. Lacy, Lead, respond, partner or ignore: the role of business schools on corporate responsibility. Corporate Governance, 5, 2, 174-185 (2005)

15. R. W. Kolodinsky, T. M. Madden, D. S. Zisk, E. T. Henkel, Attitudes about corporate social responsibility: Business student predictors. Journal of Business Ethics, 91, 2, 167-181 (2010)

16. M. G. Atakan, S. Burnaz, Y. I.. Topcu, An empirical investigation of the ethical perceptions of future managers with a special emphasis on gender-Turkish Case. Journal of Business Ethics, 82, 3, 573-586 (2008)

17. N. Cornelius, J. Wallace, R. Tassabehji, An analysis of corporate social responsibility, corporate identity, and ethics teaching in business schools. Journal of Business Ethics, 76, 1, 117-135 (2007)

18. W. G. Bennis, J. O'Toole, How business schools lost their way. Harvard Business Review, 83, 5), 96-104 (2005)

19. A. Wong, F. Long, S. Elankumaran, Business Students' Perception of Corporate Social Responsibility: The United States, China, and India. Corporate Social Responsibility and Environmental Management, 17, 299-310 (2010)

20. V. Vevere, Negotiation Ethics as Integral Part of MBA Curriculum. 3rd International Conference on Lifelong Learning and Leadership For All (Politechnica Univ. Porto, Porto, 2017, 281-289)

21. S. M. Smith, G. S. Albaum, Basic Marketing Research.(Qualtrics Labs Inc Provo, Utah., 2012) 